\title{
Implementasi Pembiayaan Murabahah Dalam Meningkatkan Kesejahteraan Nasabah (Studi di Bank Syari'ah Mitra Agro Usaha Bandar Lampung)
}

\author{
Maya Meilia ${ }^{1)}$, Andi Munandar ${ }^{2)}$, Nindi Riyana Saputri ${ }^{3)}$, \\ Sekolah Tinggi Ekonomi Dan Bisnis Islam (STEBI) Lampung \\ Email : ${ }^{1}$ maya@stebilampung.ac.id , ${ }^{2}$ andimunandar@stebilampung.ac.id , 3 nindiriyana@ stebilampung.ac.id
}

\begin{tabular}{ll}
\hline ARTICLE INFO & ABSTRACT \\
\hline Keywords: & $\begin{array}{l}\text { Sektor perbankan dewasa ini memiliki posisi yang strategis sebagai lembaga } \\
\text { intermediasi yang menunjang sistem perekonomian nasional. Oleh karena itu, peranan } \\
\text { perbankan perlu lebih ditingkatkan sesuai fungsinya dalam menghimpun dana dan }\end{array}$ \\
Murabahah, & menyalurkan dana masyarakat, khususnya dengan lebih memperhatikan pembiayaan \\
Kesejahteraan Nasabah, & kepada sektor perekonomian untuk meningkatkan kesejahteraan masyarakat. Salah \\
BPRS MAU & satunya akad dengan prinsip jual beli (murabahah). Murabahah merupakan salah satu \\
& akad pembiayaan yang digunakan oleh BPRS MAU Bandar Lampung yang diberikan \\
& kepada nasabah pelaku usaha mikro untuk peningkatan produksi, penambahan modal \\
& dan barang dagang. Menurut hasil penelitian diperoleh data bahwa Implementasi \\
& pembiayaan murabahah yang dilaksanakan pada bank MAU syariah adalah \\
pembiayaan murabahah bil wakalah yaitu dalam upaya pemberian kekuasaan kepada & nasabah untuk membeli barang yang diinginkan secara mandiri. Bertujuan untuk \\
& membantu atau memudahkan nasabah agar dapat mendapatkan hak kepemilikan atas \\
& suatu barang yang dikehendaki nasabah. Pembiayaan murabahah yang dilakukan BPR \\
& MAU Syariah disatu sisi dapat membantu nasabah yang mempunyai masalah \\
& pembiayaan dalam pemenuhan modal kerja dan keperluan konsumtif. Sehingga \\
diharapakan BPR MAU Syariah, mampu juga mengembangkan pembiayaan untuk \\
menggarap skegiatan di sektor riil secara lebih serius melalui pembiayaan berdasarkan \\
skema mudharabah dan musyarakah. Dengan demikian bank syariah dapat berperan \\
lebih signifikan didalam upaya pengembangan perekonomian nasional dalam \\
meningkatkan kesejahteraan masyarakat.
\end{tabular}

\section{PENDAHULUAN}

Perkembangan dunia perbankan di Indonesia menunjukkan pertumbuhan yang positif dan diterima baik oleh masyarakat. Indonesia sebagai Negara yang berkembang, sektor yang ikut serta berperan penting dalam pembangunan adalah sektor perbankan, diantaranya adalah perbankan yang menjalankan sistem dengan prinsip-prinsip syari'ah atau yang lazim dikenal dengan bank syari'ah. Perbankan adalah suatu lembaga yang melaksanakan 3 (tiga) fungsi utama yaitu menerima simpanan uang, meminjamkan uang dan melayani jasa pengiriman uang. Di dalam sejarah perekonomian kaum muslimin, fungsi bank telah dikenal sejak zaman Rasulullah SAW. Fungsi tersebut adalah menerima titipan harta, meminjamkan uang untuk keperluan konsumsi dan keperluan bisnis serta melakukan pengiriman uang.

Perbankan yang menjalankan prinsip-prinsip syariah juga membuktikan eksistensinya pada saat terjadi krisis keuangan global yang berlangsung antara tahun 2008-2009 yang tidak berpengaruh apapun bahkan dapat dilalui dengan baik. Sistem perbankan syariah telah membuktikan dirinya sebagai suatu sistem yang tangguh melalui krisis ekonomi di Indonesia. Dalam kondisi krisis ekonomi, bank konvensional menderita negative spread dalam bisnisnya, sebagai satu momok utama yang dihadapi oleh perbankan konvensional dan justru dalam kondisi demikian bank Islam menunjukkan kondisi yang sebaliknya. Selain dari pada itu, lembaga perbankan yang menganut sistem syari'ah tidak serta merta hanya berorientasi untuk meraup dana dari masyarakat sebanyak-banyaknya, tanpa memberi manfaat, kontribusi dan implikasi positif kepada usaha peningkatan kesejahteraan umat secara menyeluruh utamanya dalam perkembangan usaha kecil dan menengah. Tujuan bank syariah secara umum adalah untuk mendorong dan mempercepat 
kemajuan ekonomi suatu masyarakat dengan melakukan kegiatan perbankan, financial, komersial dan investasi sesuai kaidah syari'ah.

Produk-produk bank syariah diklasifikasikan berdasarkan 4 (empat) macam kategori perjanjian dalam Islam. Dalam perbankan syari'ah, setiap produk yang dikeluarkan didasarkan pada prinsip titipan, jual-beli, sewa- menyewa, bagi hasil dan akad yang sifatnya sosial (tabarru). Secara garis besar kegiatan operasional bank syari'ah dibagi menjadi 3 (tiga) kategori, yaitu kegiatan penghimpunan dana, kegiatan penyaluran dana dan jasa bank. Dari beberapa prinsip operasional tersebut, prinsip jual beli yang diwujudkan dalam akad pembiayaan muräbahah merupakan prinsip operasional yang paling populer dipraktikkan oleh bank syariah Murabahah merupakan salah satu konsep Islam dalam melakukan perjanjian jual beli. Konsep ini telah banyak digunakan oleh bank-bank dan lembaga-lembaga keungan syariah untuk pembiayaan modal kerja, konsumsi dan pembiayaan perdagangan lainnya terhadap nasabah. Murabahah juga merupakan satu bentuk perjajanjian jual beli yang harus tunduk pada kaidah dan hukum jual beli yang berlaku dalam muamalah islamiyah. Adanya fenomena bahwa muräbahah merupakan produk yang paling banyak dipraktikkan oleh bank syariah dan adanya pandangan bahwa pembiayaan murābahah merupakan produk yang mirip dengan pembiayaan kredit pada bank konvensional, menjadikan praktik pembiayaan murābahah pada perbankan syari'ah menarik untuk diteliti. Untuk itu, dalam hal ini peneliti akan melakukan penelitian tentang praktik murābahah pada perbankan syari'ah untuk mendapatkan gambaran yang sebenarnya tentang murābahah yang dipraktikkan pada perbankan syari'ah.

Berdasarkan uraian tersebut di atas, maka yang nenjadi permasalahan dalam penelitian ini yaitu tentang implementasi pembiayaan murabahah yang ada pada Bank Syari'ah Mitra Agro Usaha Bandar Lampung, dan bagaimana peran pembiayaan murabahah tersebut dalam meningkatkan kesejahteraan nasabah.

\section{LANDASAN TEORI}

\section{Pengertian Akad Murabahah}

Dalam kegiatan muamalah, hal yang paling signifikan menyangkut keabsahan hukum tersebut adalah akad. Akad menentukan sah dan tidaknya. Signifikansi akad merupakan prasyarat yang harus di penuhi. Persyaratan yang menuntut sesesorang untuk memahaminya dalam semua bentuk kegiatan muamalah supaya kegiatan yang dilakukannya sah secara hukum Islam. Kata akad berasal dari kata bahasa Arab عقد - عقدا yang berarti, membangun atau mendirikan, memegang, perjanjian, percampuran, menyatukan (Ma'luf: 1996, 518). Bisa juga berarti kontrak (perjanjian yang tercacat) (Munawir: 1997, 1023). Sedangkan menurut al-Sayyid Sabiq (1993: 12) akad berarti ikatan atau kesepakatan. Menurut Basri, akad menurut bahasa berarti ikatan (al-rabthu), kaitan (al- 'akadah) atau janji (al-'ahdu) (Basri: 2004, 24). Menurut M. Ali Hasan (2006: 101), akad berasal dari Bahasa Arab adalah (العقد) yang berarti "Perkataan, Perjanjian dan Permufakatan". Pertalian ijab (pernyataan menerima ikatan) sesuai dengan kehendak syari'at yang berpengaruh pada obyek perikatan Mustafa Ahmad Az-Zarqa (1998: 328) pakar fiqih Jordania asal Syiria menyatakan bahwa tindakan hukum yang dilakukan manusia terdiri atas dua bentuk, yaitu: Tindakan (action) berupa perbuatan, dan tindakan berupa perkataan. Berdasarkan pembagian tindakan hukum manusia di atas, menurut Mustafa Ahmad Az-Zarqa (1998: 328) bahwa suatu tindakan hukum lebih umum dari pada akad. Setiap akad dikatakan sebagai tindakan hukum dari dua atau beberapa pihak, tetapi sebaliknya setiap tindakan hukum tidak bisa disebut sebagai akad. Lebih lanjut Mustafa Ahmad Az-Zarqa menyatakan bahwa dalam pandangan syara' suatu akad merupakan ikatan secara hukum yang dilakukan oleh dua atau beberapa pihak yang sama-sama berkeinginan untuk mengikatkan diri. Kehendak Hal yang penting bagi terjadinya akad adalah adanya ijab dan qabul. Ijab-qobul adalah suatu perbuatan atau pernyataan untuk menunjukkan suatu keridhaan dalam berakad di antara dua orang atau lebih, sehingga terhindar atau keluar dari suatu ikatan yang tidak berdasarkan syara'. Oleh karena itu, dalam Islam tidak semua kesepakatan atau perjanjian dapat dikategorikan sebagai akad, terutama kesepakatan yang tidak didasarkan pada keridlaan dan syari'at Islam.

Ijab adalah pernyataan pertama yang dikemukakan oleh salah satu pihak, yang mengandung keinginannya secara pasti untuk mengikat diri. Sedangkan qabul adalah pernyataan pihak lain setelah $i j a b$ yang menunjukkan persetujuan untuk mengikatnya diri. Jadi, setiap pernyataan yang diungkapkan oleh salah satu pihak yang ingin mengikatkan diri dalam suatu akad disebut dengan mujib (pelaku ijab) dan setiap 
pernyataan kedua yang diungkapkan oleh pihak lain setelah ijab disebut dengan qabil (pelaku qabul); tanpa membedakan antara pihak mana yang memulai pernyataan pertama itu.

Pengertian murabahah secara bahasa atau etimologis adalah berasal dari kata "ribh" yang artinya "keuntungan" yaitu "pertambahan nilai modal". Kata murabahah merupakan bentuk mutual yang bermakna "saling". Jadi, murabahah artinya "saling mendapatkan keuntungan". Dalam ilmu fiqh, murabahah diartikan menjual dengan modal asli bersama tambahan keuntungan yang jelas (al-Muslih dan Ash-Shawi: 2004, 198).

Secara terminologis, yang dimaksud dengan murabahah adalah pembelian barang dengan pembayaran yang ditangguhkan (1 bulan, 2 bulan, 3 bulan dan seterusnya tergantung kesepakatan). Pembiayaan murabahah diberikan kepada nasabah dalam rangka pemenuhan kebutuhan produksi (inventory) (Karnaen dan Antonio: 2008, 25).

Di antara sistem akad jual beli yg cukup banyak ditemukan pada bank-bank adalah apa yang mereka sebut dengan istilah murabahah. Murabahah adalah transaksi penjualan barang dengan menyatakan harga perolehan dan keuntungan (margin) yang disepakati oleh penjual dan pembeli. Pembayaran atas akad jual beli dapat dilakukan secara tunai maupun kredit. Hal yang membedakan murabahah dengan jual beli lainnya adalah penjual harus memberitahukan kepada pembeli harga barang pokok yang dijualnya serta jumlah keuntungan yang diperoleh. (Karim: 2005, 113).

Penjualan dapat dilakukan secara tunai atau kredit, jika secara kredit harus dipisahkan antara keuntungan dan harga perolehan. Keuntungan tidak boleh berubah sepanjang akad, kalau terjadi kesulitan bayar dapat dilakukan restrukturisasi dan kalau kesulitan bayar karena lalai dapat dikenakan denda. Denda tersebut akan dianggap sebagai dana kebajikan. Uang muka juga dapat diterima, tetapi harus dianggap sebagai pengurang piutang.

Murabahah adalah salah satu bentuk jual-beli yang bersifat amanah. Bentuk jual-beli ini adalah kontrak jual-beli atas barang tertentu. Pada transaksi jual-beli tersebut penjual harus menyebutkan dengan jelas barang yang diperjual belikan dan tidak termasuk barang haram. Demikian juga, harga pembelian dan keuntungan yang diambil dan cara pembayarannya harus disebutkan dengan jelas seperti yang terpapar di atas (Karim: 2004, 54). Menurut teknis perbankan, murabahah adalah akad jual-beli antara bank selaku penyedia barang (penjual) dengan nasabah yang memesan untuk membeli barang. Bank memperoleh keuntungan dari jual-beli yang disepakati bersama. Berdasarkan berbagai definisi tersebut di atas, maka dapat disimpulkan beberapa hal pokok bahwa akad murabahah terdapat 1) pembelian barang dengan pembayaran yang ditangguhkan. Dengan defenisi ini, maka murabahah identik dengan ba'i bitsaman ajil. 2) Barang yang dibeli menggunakan harga asal. 3) Terdapat tambahan keuntungan (komisi, mark up harga, laba) dari harga asal yang telah disepakati. 4) terdapat kesepakatan antara kedua belah pihak (pihak bank dan nasabah) atau dengan kata lain, adanya kerelaan di antara keduanya. 5) Penjual harus menyebutkan harga barang kepada pembeli (memberi tahu harga produk).

\section{Dasar Hukum Murabahah}

Pembiayaan murabahah mendapatkan pengaturan dalam UU NO. 10 Tahun 1998 tentang perubahan atas UU NO. 7 Tahun 1992 tentang perbankan. Peraturan secara khusus terdapat dalam UU NO. 21 Tahun 2009 tentang perbankan syariah yaitu pasal 18 ayat 1 yang intinya menyatakan bahwa kegiatan usaha bank umum syari'ah meliputi antara lain menyalurkan pembiayaan berdasarkan akad murabahah, salam, istishna', atau akad lain yang tidak bertentangan dengan prinsip syari'ah (Ghofur: 2009, 108).

Di samping itu pembiayaan murabahah juga telah diatur dalam fatwa DSN No. 04/DSNMUI/IV/2002 pada tanggal 01 April 2000. Yang didalamnya menyatakan pada intinya bahwa dalam rangka membantu masyarakat guna melangsungkan dan meningkatkan kesejahteraan dalam berbagai kegiatan, bank syariah perlu perlu memiliki fasilitas murabahah bagi yang memerlukannya.

Ayat-ayat Al-Qur'an dan hadist yang dapat dijadikan rujukan dasar akad transaksi al-Murabahah, adalah ayat al-Qur'an surat Al-Baqarah ayat 275 yang Artinya: ... Allah telah menghalalkan jual beli dan mengharamkan riba... kemudian hadis Nabi yaitu yang diriwayatkan oleh HR. Ahmad dan Baihaqi yang artinya: Rasululullah Saw pernah ditanya, tentang mata pencaharian yang paling baik? Beliau menjawab: seseorang bekerja dengan tangannya dan setiap jual-beli yang mabrur. (HR. Ahmad dan Baihaqi). 
Kemudian ijma' ulama yaitu orang-orang Islam telah mempraktekkan dan bermuamalah dengan murabahah sepanjang masa tanpa ada yang menolak dan mengingkari keabsahannya. Hal ini sebagai petunjuk adanya ijma akan kebolehan murabahah (Kasani: 1982, 222). Ibnu Rusyd berkata bahwa jumhur ulama berijma tentang jual beli terbagi dua yaitu musawamah (jual beli tawar menawar) dan murabahah. (alQurtubi: tt., 213).

\section{Rukun dan Syarat Murabahah}

Rukun adalah sesutu yang tergantung atasnya sesuatu yang lain dan ia berada dalam esensi sesuatu tersebut. Sedangkan menurut Jumhur ulama fiqih, rukun adalah sesuatu tergantung sesuatu yang lain atasnya, tetapi tidak harus berada pada esensi seseuatu tersebut (Haroen: 1996, 263-264). Jadi yang dimaksud dengan rukun adalah suatu unsur penting yang menyebabkan adanya suatu pekerjaan atas pekerjaan yang lain, yang dalam hal ini adalah pekerjaan jual beli atau perdagangan murabahah.

Dalam fikih muamalah, untuk terbentuknya akad yang sah dan mengikat maka harus dipenuhilah rukun-rukun dan syarat-syarat akad tersebut. Adapun yang menjadi rukun dan syarat menurut jumhur fuqaha, rukun akad terdiri atas Berdasarkan pengertian tersebut, maka jika duhubungkan dengan pembahasan rukun akad, dapat dijelaskan bahwa rukun akad adalah kesepakatan dua kehendak, yakni ijab dan qabul. Seorang pelaku tidak dipandang sebagai rukun dari perbuatannya karena pelaku bukan merupakan bagian internal dari perbuatannya. Dengan demikian para pihak dan obyek akad adalah unsur yang berada diluar akad, tidak merupakan esensi akad, karena dia bukan merupakan rukun akad. Hal ini dapat diqiyaskan pada perbuatan shalat, dimana pelaku shalat tidak dipandang sebagai rukun dari perbuatan shalat. Oleh karena itu, berdasarkan argumen ini maka al-'Aqid (orang atau pihak yang melakukan akad) tidak dipandang sebagai rukun akad.

\section{METODE PENELITIAN}

Penelitian ini adalah penelitian lapangan (field research) yang bersifat deskriptif analitis, artinya memaparkan data-data yang ditemukan di lapangan dan menganalisisnya untuk mendapatkan kesimpulan yang benar dan akurat. Metode yang digunakan dalam penelitian ini adalah kualitatif deskriptif (Kountur: 2004, 105). Adapun penelitian ini menggunakan penelitian studi kasus yaitu penelitian yang mempelajari secara mendalam terhadap sesuatu individu, kelompok, institusi atau masyarakat tertentu, tentang latar belakang, keadaan atau kondisi, faktor-faktor atau interaksi-interaksi sosial yang terjadi di dalamnya. Karena studi ini bertujuan memperoleh gambaran secara mendalam tentang pembiayaan murabahah dalam meningkatkan ekonomi nasabah, yang secara khusus berfokus pada BPRS MAU.

Penelitian ini bersifat deskriptif, yaitu suatu penelitian yang semata-mata hanya menggambarkan keadaan dan kejadian atas suatu objek, diuraikan secara lengkap, rinci, jelas dan sistematis. Hasil penelitian dalam bentuk laporan sebagai karya ilmiah. Tujuan dari penelitian itu sendiri adalah untuk mengetahui keadaan (description of exiting reality) hubungan antara satu hal dengan hal yang lain, khususnya hubungan sebab akibat.

Sumber data dalam penelitian adalah subjek dari mana data dapat diperoleh. Sumber data dalam penelitian ini adalah sumber data primer dan sumber data sekunder. Data primer yaitu data yang diperoleh secara langsung dari pihak pertama. Data ini dapat diperoleh penulis melalui wawancara kepada direktur BPRS, manajer oprasional, marketing officer dan brosur. Dengan kata lain data ini merupakan murni yang diperoleh dari hasil lapangan tentang pembiayaan murabahah di BPRS MAU. Sedangkan data sekunder yaitu data yang diperoleh atau berasal dari bahan kepustakaan yang digunakan untuk melengkapi data primer. Penulis dapat memperoleh data sekunder dari buku-buku, baik tentang akad Murabahah maupun ketentuan-ketentuan lain yang berkaitan dengan penelitian ini.

Teknik pengumpulan data dalam penelitian ini adalah metode observasi dan wawancara. Pengumpulan data yang lebih spesifik dari masing-masing teknik tersebut dikenal sebagai observasi melibat (participant observation) dan wawancara mendalam (in-depth interview. Alat pengumpul data ini digunakan untuk memperoleh data terkait dengan penelitian ini. 


\section{HASIL PENELITIAN}

Menurut hasil penelitian, diperoleh data bahwa produk yang ditawarkan adalah produk simpanan atau tabungan dan produk pembiayaan. Simpanan tabungan yaitu simpanan atau tabungan nasabah kepada Bank MAU Syariah yang dapat diambil sewaktu-waktu, dengan besarnya tiap setoran disesuaikan dengan kebutuhan nasabah. Simpanan atau tabungan ini biasanya mendapatkan bagi hasil setiap periode (satu bulan takwim) yang besarnya disesuaikan dengan tingkat saldo yang mengendap di Bank MAU Syariah. Simpanan atau tabungan yang dikelola oleh Bank MAU Syariah yaitu: Tabungan Wadiah; Tabungan Mudharabah; dan Deposito Mudharabah.

Sedangkan produk pembiayaan atau yang sering dikenal orang dengan kredit adalah salah satu ujung tombak yang menjadi tumpuan suatu lembaga keuangan dalam mengembangkan usahanya. Dengan demikian yang dimaksud dan tujuan pembiayaan di Bank MAU Syariah dapat disamakan sesuai dengan undang-undang Perbankan, karena secara tegas membuka peluang sistem bagi hasil sesuai dengan syariah Islam.

Salah satu produk pembiayaan yang ditawarkan adalah pembiayaan Murabahah bil Wakalah. Murabahah adalah fasilitas pembiayaan melalui jual beli yang diberikan bank MAU syariah kepada nasabahnya dengan akad Murabahah bil Wakalah yaitu Murabahah yang diwakilkan. Fasilitas pembiayaan melalui penyaluran uang untuk mewakili bank dalam membeli barang.

Praktik murabahah bil wakalah pada bank MAU syariah dilakukan melalui pengikatan dua akad yaitu (Murabahah dan wakalah). Fatwa Dewan Syariah Nasional No. 04/DSN-MUI/IV/2000 tentang Murabahah pada Ketetapan Pertama butir 9. Fatwa tersebut menyebutkan bahwa jika bank hendak mewakilkan kepada nasabah untuk membeli barang dari pihak ketiga, akad jual beli murabahah harus dilakukan setelah barang, secara prinsip telah menjadi milik bank.

Mekanisme Pembiayaan Murabahah Pada BPRS MAU yaitu seorang nasabah yang ingin mendapatkan pembiayaan murabahah, ada cara dan mekanisme dalam pembiayaan tersebut, yaitu berupa syarat-syarat pembiayaan murabahah yang harus dipenuhi setiap nasabah yang ingin dibiayai oleh BPRS MAU.

Adapun yang harus dilalui dalam mekanisme tersebut, dimana nasabah adalah seseorang yang bekerja dan membutuhkan tambahan modal. Seperti nasabah yang membutuhkan mobil untuk mengangkut barang yang diusahakannya. Dan hal ini menjadi syarat bagi nasabah dan tidak untuk memulai usaha.

Barang dan benda yang dibutuhkan tersebut nasabah membeli dan memberikan tanda bukti pembelian barang tersebut dan besarannya yang sesuai dengan pengajuan nasabah dan tanda bukti tersebut diserahkan kepada pihak Bank dan dijadikan dokumentasi dalam kontrak perjanjian murabahah.

Nasabah menanggung seluruh biaya yang timbul sehubungan dengan pembiayaan ini, nasabah dalam hal ini harus siap membayar segala biaya-biaya dari seluruh kontrak perjanjian murabahah. Dalam pembiayaan murabahah, nasabah bertanggung jawab atas pembiayaan yang ditimbulkan dari akad murabahahyaitu, biaya administrasi, biaya asuransi dan biaya lain-lain. Biaya-biaya tersebut harus dibayar pada dimuka kepada pihak bank untuk dijadikan dokumen dalam pembiayaan murabahah.

\section{Implementasi Pembiayaan Murabahah}

Pada dasarnya pembiayaan murabahah di Bank MAU Syariah tersebut menggunakan sistem wakalah yaitu praktiknya dalam pembelian barang murabahah, pihak bank hanya mewakilkan kepada nasabah untuk mencari dan membeli sendiri barang yang dibutuhkan tersebut, sehingga memudahkan nasabah dalam mencari dan membeli benda/barang yang dibutuhkan nasabah untuk perkembangan usahanya. Dalam hal ini system pembayaran tersebut dilakukan secara angsuran. Jumlah kewajiban yang harus dibayarkan oleh nasabah kepada bank ialah jumlah harga barang dan mark-up (keuntungan yang telah disepakati).

Bank Syariah Mitra Agro Usaha dalam memberikan pembiayaan murabahah, menetapkan syaratsyarat yang dibutuhkan dan prosedur yang harus ditempuh oleh musytari yang hampir sama dengan syarat dan prosedur kredit sebagaimana lazimnya yang ditetapkan oleh bank konvensional. 
Ketentuan Bank Indonesia dan pemerintah, sesuai yang diatur dalam Undang-Undang No. 10 Tahun 1998 tentang Perubahan Undang-Undang No. 7 Tahun 1992 tentang Perbankan; Jaminan (dhomman), biasanya cukup dengan barang yang dijadikan obyek perjanjian namun karena besarnya pembiayaan lebih besar dari harga pokok barang (karena ada mark up) maka pihak bank mengenakan uang muka senilai kelebihan jumlah pembiayaan yang tidak tertutup oleh harga pokok barang.

Pembiayaan murabahah yang dilakukan oleh $b a^{\prime} i$ dan musytari adalah perjanjian jual-beli, jika seseorang datang kepada bank syariah dan ingin meminjam dana untuk membeli barang tertentu, misalnya mobil atau rumah, suka atau tidak suka ia harus melakukan jual-beli dengan bank syariah, bank syari'ah bertindak sebagai $b a^{\prime} i$ dan nasabah sebagai musytari, begitulah cara dari bank untuk memperoleh manfaat (keuntungan) yaitu dari laba penjualan atas barang bukan dari kelebihan yang disyaratkan dalam perjanjian pinjam-meminjam karena bagaimanapun juga bank syariah sebagai lembaga komersial pasti ingin mendapatkan keuntungan. Keuntungan yang diperoleh pihak $b a$ ' $i$ adalah mark up (laba) dari penjualan barang dalam pembiayaan murabahah. Besarnya mark up untuk setiap pembiayaan berbeda, besar kecilnya mark up dipengaruhi oleh besar kecilnya risiko yang ditanggung untuk pembiayaan tersebut, besarnya mark up justru tidak dipengaruhi oleh lamanya jatuh tempo pembiayaan seperti yang biasa diterapkan dalam perjanjian kredit pada bank konvensional yang menggunakan prinsip semakin lama suatu kredit yang diberikan maka semakin banyak pula bunga yang didapat oleh pihak bank (time value of money).

Implementasi pembiayaan murabahah dengan wakalah di Bank MAU syariah dilaksanakan dalam upaya pemberian kekuasaan kepada nasabah untuk membeli barang yang diinginkan secara mandiri. Pertama-tama, nasabah mengajukan permohonan untuk membeli suatu barang. Setelah diteliti dengan seksama, kemudian bank memberikan surat wakalah yang berfungsi sebagai surat kuasa dari bank kepada nasabah untuk dapat membeli sendiri barang yang nasabah inginkan kepada supplier. Dalam hal ini pemberian pembiayaan dari bank kemudian ditransfer ke rekening nasabah.

Setelah membeli barang, kemudian nasabah memberikan kuitansi bukti pembelian kepada bank. Sebagai bukti bahwa nasabah telah benar-benar membeli barang yang tercantum dalam perjanjian. Sebagai jaminan adalah surat BPKB atau hal lain yang telah ditentukan oleh bank. Selanjutnya, nasabah melakukan pembayaran kepada bank secara cicilan sesuai dengan jangka waktu dan ketentuan yang telah disepakati oleh kedua belah pihak.

Kesepakatan (akad) dalam pembiayaan murabahah ketika telah terjadi, maka besarnya harga sudah tidak dapat berubah lagi, namun untuk menghindari terjadinya wanprestasi oleh musytari yaitu tidak membayar ataupun terlambat mengangsur pembiayaan murabahahmaka dalam perjanjian tersebut telah disetujui sebuah klausul tentang pembayaran denda yang harus dibayar oleh musytari ketika musytari terlambat dalam melakukan pembayaran angsuran. Denda yang diterima oleh $b a{ }^{\prime} i$ bukan merupakan salah satu unsur pendapatan bank syariah $\left(b a^{\prime} i\right)$, karena denda yang diperoleh tersebut digunakan sebagai dana sosial yang salah satunya disalurkan melalui qard al-hasan, ini adalah salah satu sisi positif perbankan syariah disamping sebagai lembaga komersial perbankan syariah juga berfungsi sebagai lembaga sosial demi kemaslahatan umat.

\section{Pembiayaan Murabahah untuk Meningkatkan Ekonomi Nasabah}

Kesejahteraan yang dituntut Islam agar diwujudkan oleh umatnya bukanlah sebatas kesejahteraan yang hanya berorientasi pada pemenuhan kebutuhan materi individual, namun kesejahteraan dalam segala aspek kehidupan yang mencakup semua elemen masyarakat. Peningkatan kesejahteraan yang dimaksud kemudian tidak semata menjadi tanggung jawab orang-orang yang dalam kesehariannya hidup serba kekurangan, tetapi merupakan tangggung jawab integral dalam suatu komunitas masyarakat karena tercapainya kesejahteraan sosial akan berimbas pada kedamaian dan ketenangan yang menjadi dambaan semua anggota.

Berkait dengan kesejahteraan dan pemenuhan kebutuhan, Islam sangat menganjurkan umatnya untuk senantiasa melakukan aktifitas duniawi dengan segala pola interaksi sosial-ekonomi Berkait dengan kesejahteraan dan pemenuhan kebutuhan, Islam sangat menganjurkan umatnya untuk senantiasa melakukan aktifitas duniawi dengan segala pola interaksi sosial-ekonomi. 


\section{KESIMPULAN}

Berdasarkan uraian dari pembahasan di atas dapat dikemukakan beberapa kesimpulan yaitu : Implementasi pembiayaan murabahah yang dilaksanakan pada bank MAU syariah adalah pembiayaan murabahah bil wakalah yaitu dalam upaya pemberian kekuasaan kepada nasabah untuk membeli barang yang diinginkan secara mandiri. Bertujuan untuk membantu atau memudahkan nasabah agar dapat mendapatkan hak kepemilikan atas suatu barang yang dikehendaki nasabah. Pembiayaan murabahah yang dilakukan BPR MAU Syariah disatu sisi dapat membantu nasabah yang mempunyai masalah pembiayaan dalam pemenuhan modal kerja dan keperluan konsumtif. Sehingga diharapakan BPR MAU Syariah, mampu juga mengembangkan pembiayaan untuk menggarap skegiatan di sektor riil secara lebih serius melalui pembiayaan berdasarkan skema mudharabah dan musyarakah. Dengan demikian bank syariah dapat berperan lebih signifikan didalam upaya pengembangan perekonomian nasional dalam meningkatkan kesejahteraan masyarakat.

Meskipun penelitian ini telah menunjukkan praktik-praktik riil di lapangan tentang penerapan akad murābahah, namun kebenaran yang ditemukan dalam penelitian ini tentunya sangat dibatasi oleh ruang dan waktu. Oleh karena itu, tentunya di sana masih terdapat celah-celah kelemahan baik secara metodologis maupun substansi. Untuk itu, diharapkan kepada para intelektual yang akan melakukan studi di kemudian hari untuk melakukan verifikasi atas temuan-temuan dalam penelitian ini, jika memungkinkan.

\section{REFERENSI}

Al-Kassani, Bada'i al-Shana 'i, Beirut: Dar al-Kitab al-Araby, 1982, Cet. 2, juz 5.

al-Qurtubi, Muhammad bin Ahmad bin Rusydi, Bidayah al-Mujtahid wa Nihayah al-Muqtashid, Jeddah : AlHaramain, tt, juz 2.

Ansori, Abdul Ghofur, Perbankan Syariah di Indonesia, Yogyakarta : Gadjah Mada University Press, 2007.

Antonio, Muhammad Syafi' I Bank Islam : Dari Teori ke Praktek, Jakarta : Gema Insani Press, 2002.

Anwar, Syamsul, Hukum Perjanjian Syari'ah, Jakarta: PT Raja Grafindo Persada, 2010.

Ascarya, Akad dan Produk Bank Syari'ah, Jakarta : PT. Raja Grafindo Persada, 2012.

Atmadja, Karnaen A. Perwata an Muhammad Syafi'I Antonio, Apa dan Bagaimana Bank Islam, Yogyakarta : PT. Dana Bhakti Prima Yasa, 2008.

Az-Zarqa, Mustafa Ahmada, Al-Madkhul al-Fiqhi al-'Am al-Islami fi Tsaubihi al-Jadid, Jilid I, Beirut: Dar al-Fikr, 1998.

Basri, Hasan, Kontekstualisasi Transaksi Jual Beli dalam Sistem Ekonomi Islam, dalam Aiyub Ahmad, Transaksi Ekonomi : Perspektif Hukum Perdata dan Hukum Islam, Jakarta: Kiswah, 2004.

Ghafur, Abdul, Perbankan Syari'ah Di Indonesia, Yogyakarta : Gajah Mada University Press, 2009.

Haroen, H. Nasrun, Ushul Fiqh I, Jakarta : Logos Publishing House, 1996.

Karim, Adiwarman A. Islamic Banking: Fiqh and Financial Analysis, Jakarta : PT Raja Grafindo Persada, 2005.

Ma'luf, Louis, Al-Munjid fi al-Lughat wa al- 'Alam, Beirut: Dar al-Masyriq, 1996.

Muhammad, Manajemen Bank Syari'ah, Yogyakarta: UPP. AMP. YKPN, 2007.

Sabiq, Al-Sayyid, Fiqh Al-Sunnah, jilid 3, Beirut: Dar Al-Fikr, 1993, Cet. Ke-3. 